\title{
Evaluation the Efficiency of Various Types of Corrosion Inhibitors Used for Basrah Water Storage Tanks
}

\author{
Haider Hadi Jasim ${ }^{1}$, Read Abd Al-Hussain ${ }^{2}$, Ahmed Shawqi Sadeq ${ }^{3}$
}

\begin{abstract}
Authors affiliations:
1) Chemical Eng. Dept., Basrah University, Basrah, Iraq raidhani73@yahoo.com

2) Chemical Eng. Dept., Basrah University, Basrah, Iraq $\underline{\text { Raedshuwaill@yahoo.com }}$

3) Chemical Eng. Dept., Basrah University, Basrah, Iraq Ahmedalrubaie444@gmail.com
\end{abstract}

\section{Paper History:}

Received: $13^{\text {th }}$ Feb. 2020

Revised: 24th March 2020

Accepted: $14^{\text {th }}$ Aug. 2020

\begin{abstract}
In this paper, the efficiency of six different types of corrosion inhibitors used in Basrah drinking water tanks was assessed using a potentiostatic test method. The mechanism of adsorption of silicate and phosphate inhibitors in AISI 316 stainless steel surfaces and the effects of different water components in inhibitors are discussed in detail. The values of corrosion rate obtained from the Potentiostatic test showed that the protection against corrosion in the presence of inhibitors is better compared to the case of absence of inhibitors. The results of the six types of corrosion inhibitors tested showed that the inhibitory efficacy is higher below the temperatures $45^{\circ} \mathrm{C}$, but when raise the temperature above $45^{\circ} \mathrm{C}$ the inhibitory efficiency becomes to decrease. Also, the test results indicated that the corrosion inhibitor involves silicate products provided more inhibited efficiency compared to the phosphate inhibitor alone or used the combined silicate/phosphate corrosion inhibitor. The inspection of the surface of the tested samples using optical methods shows that the pitting corrosion is demonstrated on the specimen surfaces after testing with or without inhibitors.
\end{abstract}

Keywords: Silicates Inhibitor, AISI 316, Potentiostatic Test, Adsorption, Diffusion.

$$
\begin{aligned}
& \text { تقييم الكفاءة لأنواع مختلفة من مثبطات التاكل المستخدمة في خزانات مياه البصرة } \\
& \text { حيدر هادي جاسم، رائد عبد الحسين ذياب، احمد شوقي صادق } \\
& \text { في هذه البحث تم تقييم ستة أنواع خخلفة من مثبطات الناكل المستخدمة لخزان المياه الصالحة للشرب باستخدام }
\end{aligned}
$$

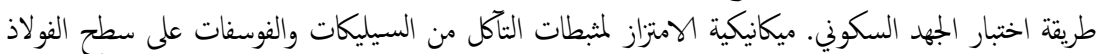

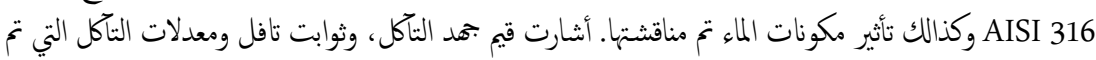

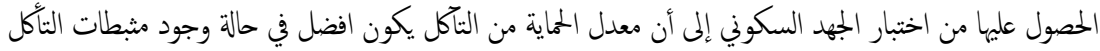

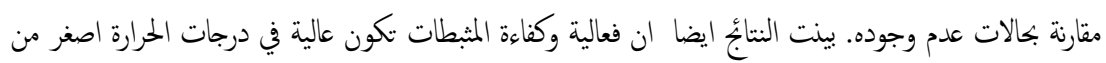

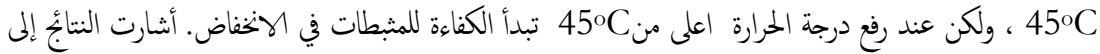

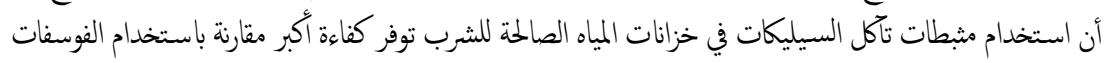

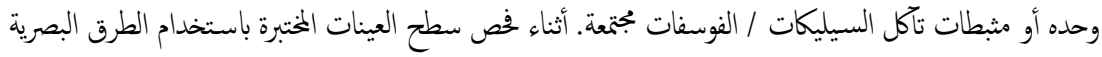

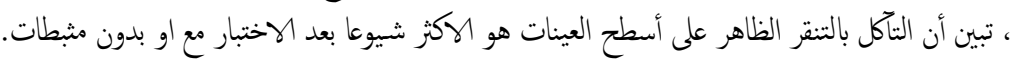

\section{Introduction}

In all provincial towns in Iraq, elevated and ground-level potable water storage tanks are spread. These tanks are used to store and supply safe and clean drinking water [1]. All forms of these water tanks are constructed using various types of stainless steel such as AISI 316, AISI 316L and ASTM 304, using a bolted, threaded joints or welding process [2]. In the city of
Al-Zubair, south of Basra from Iraq, there are four tanks used for storage drinking water built from AISI 316 stainless steel. The employment of AISI 316 stainless steel can afford economic benefits to water industry both lower initial fabricated, saving, recycle, maintained and operating cost, finished tanks handling clean waters of drinking quality [3]. The tank walls are almost subjected to water making them susceptible to corrosion damage. Corrosion is a normal

NJES is an open access Journal with ISSN 2521-9154 and eISSN 2521-9162

This work is licensed under a Creative Commons Attribution-NonCommercial 4.0 International License 
phenomenon that is based on metallurgy, the law's chemistry and electricity. Various approaches are used to control of tanks internal corrosion includes coatings and add corrosion inhibitors [4].

By using the inhibitors as a protection method, corrosion may be minimized in the drinking water storage tanks. Because of their low cost and good performance, this form of anticorrosion method has a worldwide perspective [5]. The corrosion inhibitor is a natural or industrial product if it was existed in the in the gases or water media in the appropriate quantity; it minimizes the corrosion process by minimizing the contact between metal and corrosion media [6]. For water tanks, commonly two types of inhibitors were used according to action, economic, solubility in water and toxicity. These are silicate inhibitor and phosphate inhibitor or some time's inter-mixture between them [7].

The use of silicate and phosphates as inhibitors of corrosion of metals in potable water is due to nontoxic effect of such chemicals as they are safe regarding the human health. These inhibitors, when dissolve in potable water, form non-toxic compounds that have a strong tendency to remain in a solid state, adhere on the surface to form a protective layer that restrains the corrosion [8].

Several studies are performed to examine the inhibition effects of certain types of inhibitors that include phosphate or silicate as the key components used for potable water storage tank. Strehblow [9] showed that the chloride and sulphate ions are the main sources of creation of stainless steel alloys localized corrosion. It has also been suggested that the existence of bicarbonate slow down the impact of these two ions on stainless steel corrosion. Nausha, et al. [10] studied the sodium silicate corrosion inhibition properties using immersion and electrochemical tests methods of steels alloy in drinking waters of Saudi Arabia under both of static and flow conditions. Results obtained from the experimental tests show a positive effect of inhibition of sodium silicate in the regulatory of steel corrosion used for clean water. Mcneill, et al. [11] studied the addition of polyphosphate inhibitor to drinking water. They showed that it was prevented the reactions at anodic parts and also the polyphosphate may be influences on the dissociation of the oxide film that deposition at metal surfaces. Ebrahimi, et al. [12] studied the influences of polyphosphate and sodium-silicate in the delivery drinking water by experimental techniques. Their results confirmed that the polyphosphates or sodium-silicate gives effective on protection and slow down the oxidation process. Mathiesen, et al. [13] reviewed the rare corrosion failures of stainless steel AISI 304 and 316. They discussed the corrosion problems of river and drinking water contained small quantity of chloride. They collected and discussed the corrosion failure investigations, hydrostatic testing and achievable theories for predicting the corrosion phenomenon. Nurul, et al. [14] studied the effects of $\mathrm{pH}$, temperature and inhibitor adsorption of mild steel in $1 \mathrm{M} \mathrm{HCl}$ solution by utilizing of experimental techniques. Results demonstrated that the protection process is endothermic in nature and the adsorption process is important parameters in which to clarify how the inhibitor works. Daniela, [15] studied the performance of phosphate-silicate inhibitor in different types of pipes used for drinking water distribution. The results showed that the stabilized of water $\mathrm{pH}$ and chlorine concentration decreasing his oxidation process in the water translation system. Kazem, et al. [16] inspected the performance of inhibition of sodium-phosphate using experimental electrochemical techniques. Their results showed the brushing process supported the passivity and this was attributable to a large atomic site density that improved the adsorption of sodium-phosphate components and make on lowering corrosion levels.

\section{Objectives}

The goal of this paper is to assess the efficiency and inhibitor rates of various types of corrosion inhibitors used for potable water storage tanks. The corrosion test was achieved using the method of electrochemical Potentiostatic measurements on AISI 316 stainless steels, and the corrosion rate is obtained by Tafel polarization method.

\section{Experimental Methods}

\subsection{AISI 316 Stainless Steel Specimens}

The materials used in this experimental work is the commercial stainless steel grade AISI 316, which is widely used for constricting water storage tanks and available on the Iraqi market. Table 1 show their chemical composition (wt. \%). The specimen used for the potentiostatic corrosion test is shown in Figure (1). The test specimens used in the Potentiostatic corrosion test have a $20 \mathrm{~mm}$ diameter and $4 \mathrm{~mm}$ thick circular form.

Table 1: The Constituent Elements of AISI 316 Stainless Steel [17].

\begin{tabular}{|c|c|}
\hline Elements & Mass $\%$ \\
\hline $\mathrm{Cr}$ & $16-18$ \\
\hline $\mathrm{Mn}$ & 2 \\
\hline $\mathrm{Ni}$ & $10-14 \mathrm{Max}$. \\
\hline $\mathrm{C}$ & $0.1 \mathrm{Max}$. \\
\hline $\mathrm{Si}$ & 1 \\
\hline $\mathrm{Mo}$ & $2-3$ \\
\hline $\mathrm{N}$ & 0.1 \\
\hline $\mathrm{P}$ & 0.045 \\
\hline $\mathrm{S}$ & 0.030 \\
\hline
\end{tabular}

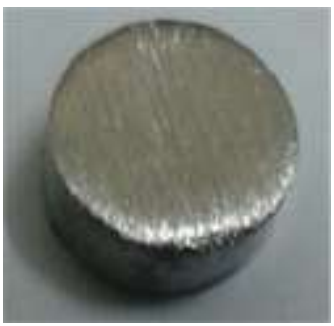

Figure 1: AISI 316 Stainless Steel Test Specimens.

\subsection{Corrosion Inhibitors for Testing}


Corrosion inhibitors are organic and inorganic compounds which can be present in any type of solids, liquids, and gasses. Most of corrosion inhibitor used for drinking water storage tanks contains phosphate and silicate inhibitors [18]. In last year, dissimilar forms of inhibitors have been used for protecting the potable water storage tanks in southern Iraq. Six types of inhibitors were used in this study for testing. Refer as model $\mathrm{A}$, model $\mathrm{B}$, model $\mathrm{C}$ and model $\mathrm{D}$ for inhibitors contains primary silicate based inhibitor. Refer as model E for a polyphosphate based corrosion inhibitor and a model $\mathrm{F}$ for phosphate/silicate inhibitor. Table 2 listed their types of tested inhibitors and manufactured companies. The information in Table 2 was obtained from the manufactured companies.

Table 2: Corrosion Inhibitors Types For Potable

Water Tanks And Manufacturing Company

\begin{tabular}{|c|c|c|}
\hline Models & $\begin{array}{c}\text { Corrosion inhibitor } \\
\text { types }\end{array}$ & $\begin{array}{l}\text { Manufacture } \\
\text { company }\end{array}$ \\
\hline A & $\begin{array}{l}\text { Water tank } \\
\text { corrosion inhibitor } \\
\text { TCL-599 (silica - } \\
\text { based product) }\end{array}$ & $\begin{array}{l}\text { Superior } \\
\text { Industries, Inc., } \\
\text { USA. }\end{array}$ \\
\hline B & $\begin{array}{l}\text { Water Corrosion } \\
\text { Inhibitor (liquid) }\end{array}$ & $\begin{array}{l}\text { MKW Bio- } \\
\text { Systems, } \\
\text { Mumbai, India. }\end{array}$ \\
\hline C & $\begin{array}{l}\text { Potable water } \\
\text { corrosion inhibitor } \\
\text { (silica based } \\
\text { product) (RXSOL- } \\
32-3112-025) \\
\end{array}$ & $\begin{array}{l}\text { Production by } \\
\text { Visakhapatnam } \\
\text { Co., Mumbai, } \\
\text { India. }\end{array}$ \\
\hline $\mathrm{D}$ & $\begin{array}{l}\text { Potable Water } \\
\text { Corrosion Inhibitor } \\
\text { Pol (silica based } \\
\text { product) RXSOL- } \\
40-4094-025 \\
\end{array}$ & $\begin{array}{l}\text { Industrial and } \\
\text { Marine Suppliers } \\
\text { BIO, India. }\end{array}$ \\
\hline $\mathrm{E}$ & $\begin{array}{l}\text { AWC A-700 } \\
\text { polyphosphate } \\
\text { based inhibitor }\end{array}$ & $\begin{array}{l}\text { American Water } \\
\text { Chemicals Inc., } \\
\text { USA. }\end{array}$ \\
\hline F & $\begin{array}{l}\text { Accepta } 2895 \\
\text { phosphate/silicate } \\
\text { corrosion inhibitor }\end{array}$ & $\begin{array}{l}\text { Accepta Water } \\
\text { Treatment Inc., } \\
\text { UK. }\end{array}$ \\
\hline
\end{tabular}

\subsection{The Potentiostatic Corrosion Test Technique}

The array of possible apparatuses used in research to perform the Potentiostatic test is illustrated in Figure (2). It is involved the M-Lap desktop instrument operated by a computer and connected to the three electrodes cell. The working electrode is represented by the AISI 316 stainless steel specimens. The counter electrode was manufactured from Platonized Titanium (Pi-Ti) and used to measure corrosion current. The reference electrode is contains the silver chloride as a saturated solution. The glass cell that has been used to test is a $500 \mathrm{ml}$ glass baker. A water bath heater (within $\pm 0.1^{\circ} \mathrm{C}$ precision) containing water solution is used for regulating the temperature of potable water interior the glass cell during test running.
The drinking water was taken from Basrah storage tanks at R-zero-plants and used as a solution for Potentiostatic testing. The Spectrophotometer was utilized for analyzing the Basrah drinking water material compositions and the results are given in Table 3. The $\mathrm{pH}$ and TDS values of potable water tested are determined in a laboratory and have values of $\mathrm{pH}=8.21$ and TDS $=110 \mathrm{ppm}$ respectively. A titrimetric method is used to measure the oxygen dissolved in potable water in a laboratory and the value is given in Table 3. All data given in Table 3 is measured laboratory at chemical engineering dept., Basrah University.

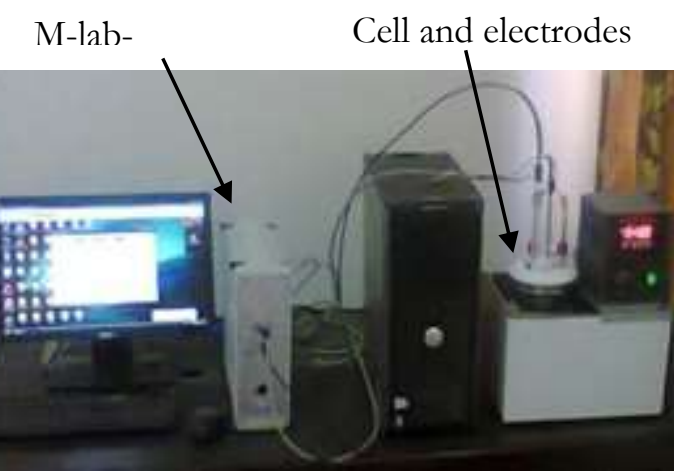

Figure 2: M-Lap Potentiostatic Test Collection.

Table 3: Materials Analysis And Oxygen Dissolved Of Basrah Drinking Water.

\begin{tabular}{|c|c|}
\hline Elements & Concentrate $(\mathrm{ppm})$ \\
\hline $\mathrm{Cu}$ & 0.01 \\
\hline $\mathrm{Ni}$ & $76 * 10^{-2}$ \\
\hline $\mathrm{Al}$ & $19 * 10^{-2}$ \\
\hline $\mathrm{Fe}$ & 4 \\
\hline $\mathrm{Mn}$ & 1.3 \\
\hline $\mathrm{Fl}$ & 25 \\
\hline $\mathrm{Na}$ & 715.09 \\
\hline \hline $\begin{array}{c}\text { Chloride and } \\
\text { calcium elements }\end{array}$ & Concentrate $(\mathrm{mg} / \mathrm{l})$ \\
\hline $\mathrm{Cl}$ & 30 \\
\hline \hline $\mathrm{Ca}$ & $<5 \mathrm{mg} / \mathrm{l}$ \\
\hline $\mathrm{O}_{2}$ dissolved
\end{tabular}

The glass cell is filled with $0.5 \mathrm{~L}$ of a potable water and then set it in the water bath to control the temperature for each test. During a waiting time of (2h), the specimen was under open circuit conditions in the M-Lap Potentiostatic apparatus and the open circuit potential was recorded at the end of the exposure period. Then the potential is applied at the working electrode (test specimen) at a scan rate of 4 $\mathrm{mV} / \mathrm{s}$ starting from $\pm 250 \mathrm{mV}$ with respect to the open circuit potential according to ASTM methods [19]. The quantity of inhibitors are added during a test according to data given by manufactured company. Models A, B, C and D will add by the quantity 32 ppm for each $1 \mathrm{~L}$ of potable water, while the other models $\mathrm{E}$ and $\mathrm{F}$ will add by a quantity of $3 \mathrm{mg} / \mathrm{l}$.

The corrosion test by M-Lap Potentiostatic apparatus is controlled and operated via a computer. The data is recorded through a esting involves the corrosion currents, voltage, time of testing and the 
data processing. The program software version 5.1.exe is used to control the M-Lap apparatus throughout test running. The results of the experiment test are a graphical output between the log current versus applied potential. The curve is then analysis by using a Tafel linearization method to acquire the values of Tafel constants ( $\mathrm{I}_{\text {corr. }}$ and $\mathrm{E}_{\text {corr. }}$ ) which is then used in calculating of corrosion level.

The corrosion rate $\left(\mathrm{C}_{\mathrm{r}}\right)$ as a penetration rate per unit time ( $\mathrm{mm} /$ year) at a test temperature is calculated by the following relation [20]:

$$
\mathrm{C}_{\mathrm{r}}=3.27 * 10^{-3} * \frac{\mathrm{i}_{\text {corr. }}}{\rho_{\mathrm{m}}} \mathrm{E}_{\mathrm{w}}
$$

The value of $\mathrm{i}_{\text {corr. }}$ is estimated from the following relation [19]:

$$
i_{\text {cor. }}=\frac{I_{\text {corr. }}}{A_{s}}
$$

Where,

$\mathrm{A}_{\mathrm{s}}$ : Surface area of test specimen $\left(\mathrm{cm}^{2}\right)$.

$\rho_{m}$ : Density of stainless steel metal $\left(\mathrm{g} / \mathrm{cm}^{3}\right)$.

$\mathrm{I}_{\text {corr.: }}$ Represent a corrosion current calculated from Tafel plot in $(\mathrm{mA})$.

In Eq.1 the equivalent weight $\left(\mathrm{E}_{\mathrm{w}}\right)$ is calculated from known the composition of AISI 316 specimen from the following relation [20]:

$$
\mathrm{E}_{\mathrm{w}}=\frac{1}{\sum \frac{\mathrm{n}_{\mathrm{i}} \mathrm{F}_{\mathrm{i}}}{\mathrm{A}_{\mathrm{i}}}}
$$

Where,

$A_{i}$ : Atomic mass $(\mathrm{g} / \mathrm{mol})$ of the element $\mathrm{i}$.

$n_{\mathrm{i}}$ : Valiancy of element $\mathrm{i}$.

$\mathrm{F}_{\mathrm{i}}$ :The perecentage fraction of any $\mathrm{i}$ component within the stainless steel.

From the corrosion rates values in case of absence and existence of inhibitors, the values of inhibition efficiency $\left(E_{\mathrm{f}} \%\right)$ is calculated using the following equation [21]:

$$
\mathrm{E}_{\mathrm{f}} \%=\frac{\mathrm{C}_{\mathrm{r}}-\mathrm{C}_{\mathrm{ir}}}{\mathrm{C}_{\mathrm{r}}} * 100
$$

Where,

$\mathrm{C}_{\mathrm{ir}}$ : Corrosion rate in existence of inhibitor.

$\mathrm{C}_{\mathrm{r}}$ : Corrosion rate in the absence of inhibitor.

\section{Results and Discussion:}

The result obtained from the Potentiostatic experiment test is drwan as curves of polarization, Figures (3) and 4 indicate a polarization curves at $25^{\circ} \mathrm{C}$. The polarization curve is schemed between the applied potential in $(\mathrm{mV})$ versus $\log$ current in $\left(\mu \mathrm{A} / \mathrm{cm}^{2}\right)$. Figures (3) and (4) viewing polarization curves for AISI 316 tested specimens in two cases, firstly, a lack of inhibitors and second by adding the six types of inhibitors separately. As shown in Figures (3) and (4), all curves included two separate parts: the first is the anode portion where AISI 316 tested specimens dissolved (oxidized) and this increased in the positive direction, due to electrons losses. The second is a cathodic portion where the reduction process happens and this growth in the negative direction, as electrons are acquired. With the Tafel extrapolation method, the
Tafel parameters (Ecorr. and Icorr.) are given by the intersection of drawing tangential lines for each part of the anode and cathodic curves in Figure (3). From Figures (3) and (4), the othet corrosion parameters are obtained by projecting points from curves, and all parameters are summarized in a Table 4.

It appeared from Figures (3) and (4), that the adding of the inhibitors effects on both reactions occurs at the anode and cathode parts of the Potentiostatic test and the reaction rates at the two parts has been reduced. In addition, the slope of the polarization curves demonstrated the velocity of the reactions between the surfaces of stainless steel specimen with components of potable water. The inhibitor decreases the anodic and cathode Tafel curved slope and raises curves oscillation compared to case without inhibitors. The additive of the inhibitors to the potable water solution changes the Ecorr. in the impressive path and reduces the corrosion current, which should be imported from the lowering the current of anodic part for the stainless steel when the six types of inhibitors are supplemented to the potable water solution. A slight shift in potential results in a relatively large current change which means that the greater the change in reaction velocity and then a larger transmitted electron during tests. During experiments, adding inhibitor to potable water induces a large oscillation in all curves of Figure (4). Also, it can be noted from Figure 4 that model $\mathrm{E}$ and model $\mathrm{F}$ showed a great change in the curve compared to other models.

It shows from Figures (3) and (4) that all polarization curves follow Tafel plots and all samples with or without inhibitors have been passivated due to the inhibitor film formed. The polarization curves in Figures (3) and (4) can be classified into three zones: active, passive and the trans-passive zones. The passive layer created on the AISI stainless steel surface with or with inhibitors, which prevented the communication of ions between the potable water and stainless steel surface, hence, decreasing the corrosion level.

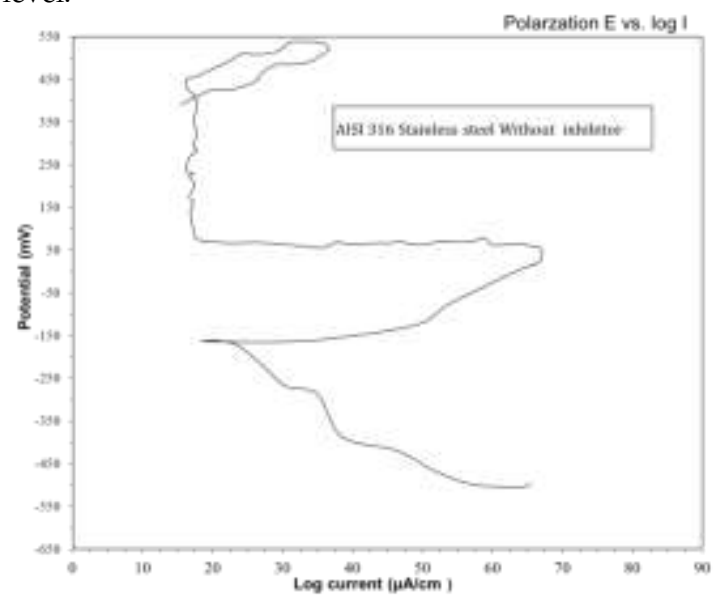

Figure 3: Polarization Curve for AISI Stainless Steel At $25^{\circ} \mathrm{C}$ For Case of Absence Inhibitor. 


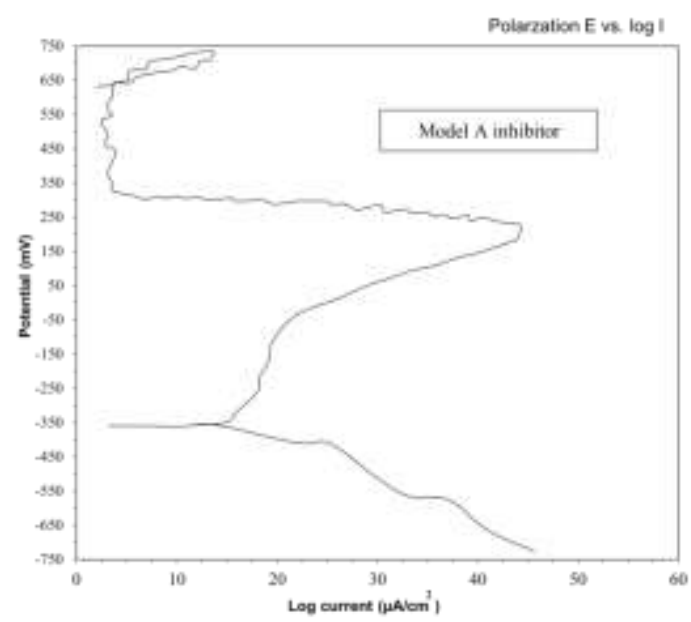

A- Model A inhibitor

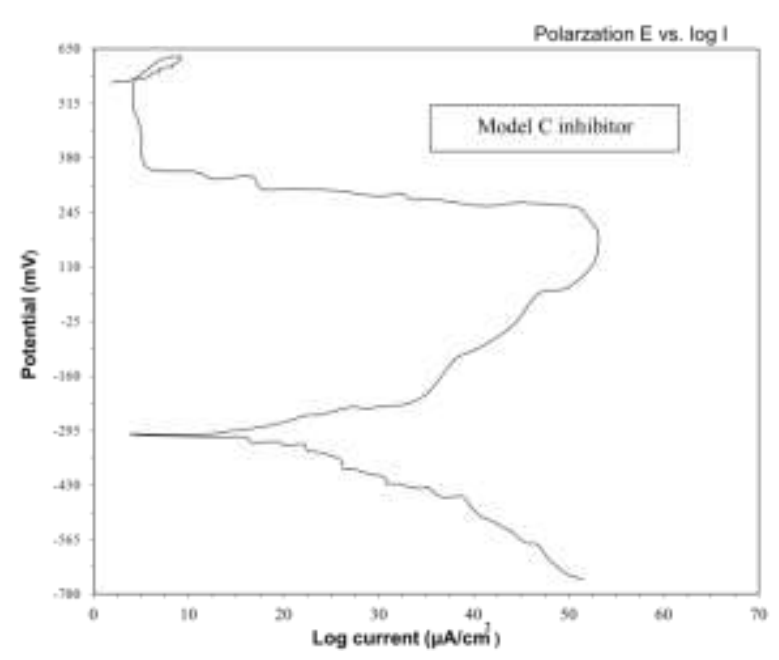

C- Model C inhibitor

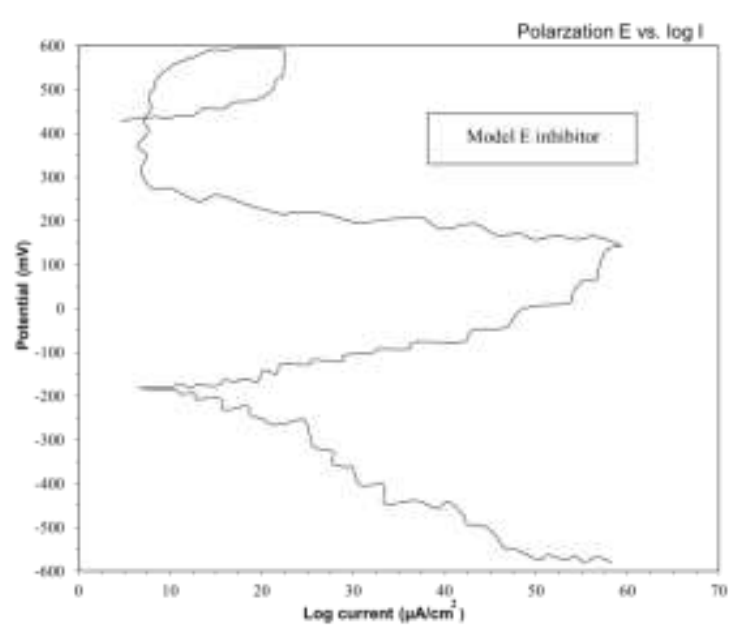

E- Model E inhibitor

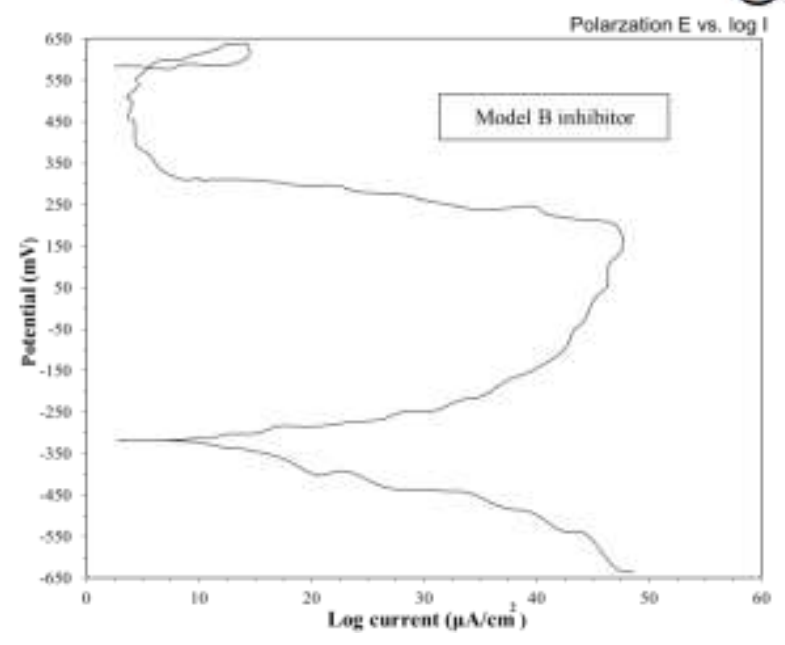

B- Model B inhibitor

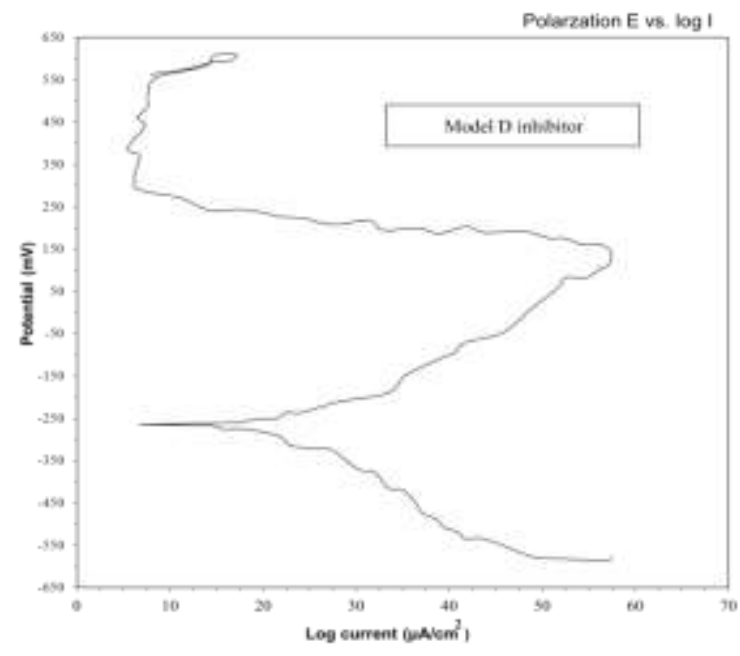

D- Model D inhibitor

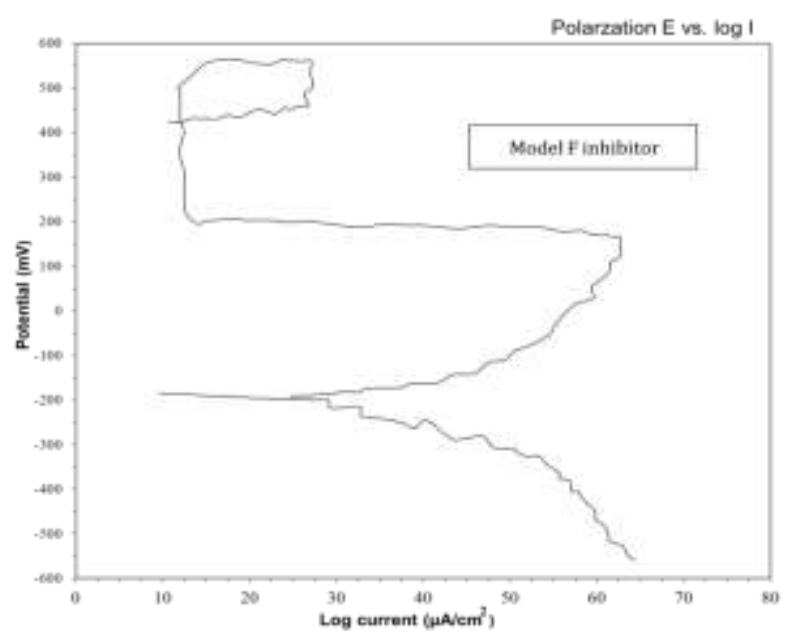

F- Model F inhibitor

Figure 4: Polarization Curves For AISI Stainless Steel At $25^{\circ} \mathrm{C}$ In Case of Existing Inhibitors.

Table 4: Corrosion Parameters Obtained From Figures 3 And 4 At $25^{\circ} \mathrm{C}$. 


\begin{tabular}{|c|c|c|c|c|c|c|c|}
\hline \multirow{2}{*}{ Parameters } & \multirow{2}{*}{$\begin{array}{c}\text { Without } \\
\text { inhibitor }\end{array}$} & \multicolumn{7}{|c|}{ Models of inhibitors } \\
\cline { 3 - 8 } & -160 & -365 & -330 & -300 & -260 & -200 & -193 \\
\hline$E_{\text {corr. }}(\mathrm{mV})$ & 45.04 & 9.46 & 11.71 & 13.03 & 16.66 & 18.46 & 20.72 \\
\hline $\log I_{\text {corr. }}\left(\mu \mathrm{A} / \mathrm{cm}^{2}\right)$ & 49 & 240 & 210 & 200 & 175 & 151 & 140 \\
\hline $\mathrm{E}_{\text {passive }}(\mathrm{mV})$ & 17.5 & 3 & 4.5 & 6 & 7.0 & 7.3 & 12.5 \\
\hline $\mathrm{I}_{\text {passive }}\left(\mu \mathrm{A} / \mathrm{cm}^{2}\right)$ & 350 & 650 & 580 & 560 & 550 & 512 & 500 \\
\hline $\mathrm{E}_{\text {translation }}(\mathrm{mV})$ & 78 & 46 & 48 & 53 & 57 & 59 & 64 \\
\hline $\mathrm{I}_{\text {critical }}\left(\mu \mathrm{A} / \mathrm{cm}^{2}\right)$ & 450 & 740 & 640 & 620 & 600 & 580 & 550 \\
\hline $\mathrm{E}_{\text {transpassive }}(\mathrm{mV})$ & 410 & 630 & 565 & 525 & 515 & 425 & 420 \\
\hline $\mathrm{E}_{\text {pit }}(\mathrm{mV})$ & & & & & & & $\mathrm{B}$ \\
\hline
\end{tabular}

To acquire the corrosion rates at various temperatures in cases of existence and absence of corrosion inhibitors, the experimental Potentiostatic corrosion test is performed under various applied temperatures on potable water. After that, we used the Tafel polarization method to obtain the corrosion current and used Eq.2 to compute the corrosion current density. The equivalent weight value $\left(\mathrm{E}_{\mathrm{w}}\right)$ is computed from Eq.3 which is equal to $25.5 \mathrm{~g} / \mathrm{mol}$. After obtained the corrosion current density and equivalent weight of AISI 316 stainless steels, the values of corrosion level is calculated using Eq.1.

Figure (5) shows the rate of metal losses due to corrosion in $(\mathrm{mm} / \mathrm{y})$ as a function of temperature in $\left({ }^{\circ} \mathrm{C}\right)$ obtained from achieved the Potentiostatic corrosion test of AISI 316 stainless steels in potable water in the absence and existence of the six different types of inhibitors. As shown in Figure (5), the corrosion inhibitors reduced the corrosion rates by various degrees. The difference in protection performance between the these sorts of inhibitors depending on various factors include the ability of inhibitor molecules and atoms to donor the electrons, the geometry of molecular of inhibitor, the size of the molecule inhibitor, the dispersibility and solubility of the tested inhibitors.

The mechanism of corrosion inhibition by silicates and polyphosphate inhibitors is by creating a thin film on the surface of the metal. After addition the corrosion inhibitors in potable water, it is usually spread on a stainless steel surface by dispersion it in a solution. After adding the inhibitor, it is found from glass cell observation that all inhibitor tested show a homogeneous and heavier layer initiation. Also, it noticed that model A inhibitor shows an extra homogeneous and thicker film compared to the other inhibitor tested.

Table 5 illustrated the inhibition efficiency $\left(\mathrm{E}_{\mathrm{f}} \%\right)$ which is calculated using Eq.4 from the values of corrosion rates obtained from Figure (5) in case of existence and absence of inhibitors at various temperatures.

As illustrated from $\mathrm{I}_{\text {corr. }}$ and $\mathrm{E}_{\text {corr. }}$ values given in Table 4 , added of inhibitor produces a reduction in
$I_{\text {corr. }}$ and as the $I_{\text {corr. }}$ values decreases leads to a decrease of $E_{\text {corr. }}$ potential values or shift it to an anodic part potential. It is shown from Figure 4, the values of corrosion obtained from tests of dissimilar six inhibitors show that the inhibitory efficiency is excellently below the temperature $45^{\circ} \mathrm{C}$, but after this temperature the efficiency becomes to decrease. Hence, we can note that from Table 5 the inhibitory efficacy $\left(E_{f} \%\right)$ depends on the temperature and decreases with the rise of temperature from 10 to $55^{\circ} \mathrm{C}$. It is illustrated from Table 5 the efficiency of model $\mathrm{A}$ is $77.32 \%$ at a $10^{\circ} \mathrm{C}$, but it decreased to a value of $72.83 \%$ at $55^{\circ} \mathrm{C}$. For a model $\mathrm{F}$ the efficiency is $53.13 \%$ at $10^{\circ} \mathrm{C}$ and decreased to $46.43 \%$ at $55^{\circ} \mathrm{C}$. Furthermore raising the temperature causes reduces the bond strength in silicate or phosphate inhibitor which do on increases the inhibitor solubility in water which leads to increase the diffusion of water compounds through inhibitor films. Also, raising the temperature affects the distribution of inhibitor on stainless steel surface and inhibitor precipitation which effect in corrosion protects.

Model A contains silicate inhibitor with different additive are given the lowest values of corrosion rates, while model $\mathrm{F}$ involves silicate/phosphate inhibitor is given the largest values of corrosion rate, other types show moderate values. The use of silicate corrosion inhibitors in potable water stainless steel tanks is best and it has more efficiency compared to use of the phosphate alone or used combined silicate/phosphate corrosion inhibitors. This attributed to the silicate corrosion inhibitors containing multiple bonds, compared to phosphate alone or used combined silicate/phosphate corrosion inhibitors.

The increase in temperature will cause morphology changes in the silicate/phosphate inhibitor and this may introduce a structural distortion in the type of distortions in a lattice and changes in bond energy. These changes play in introduced flaws in the silicate/phosphate inhibitor lattice, which causes improved leakage behavior, which make a sure fewer species of corrosion inhibiting existent in the potable water media for a regulator of corrosion level. 


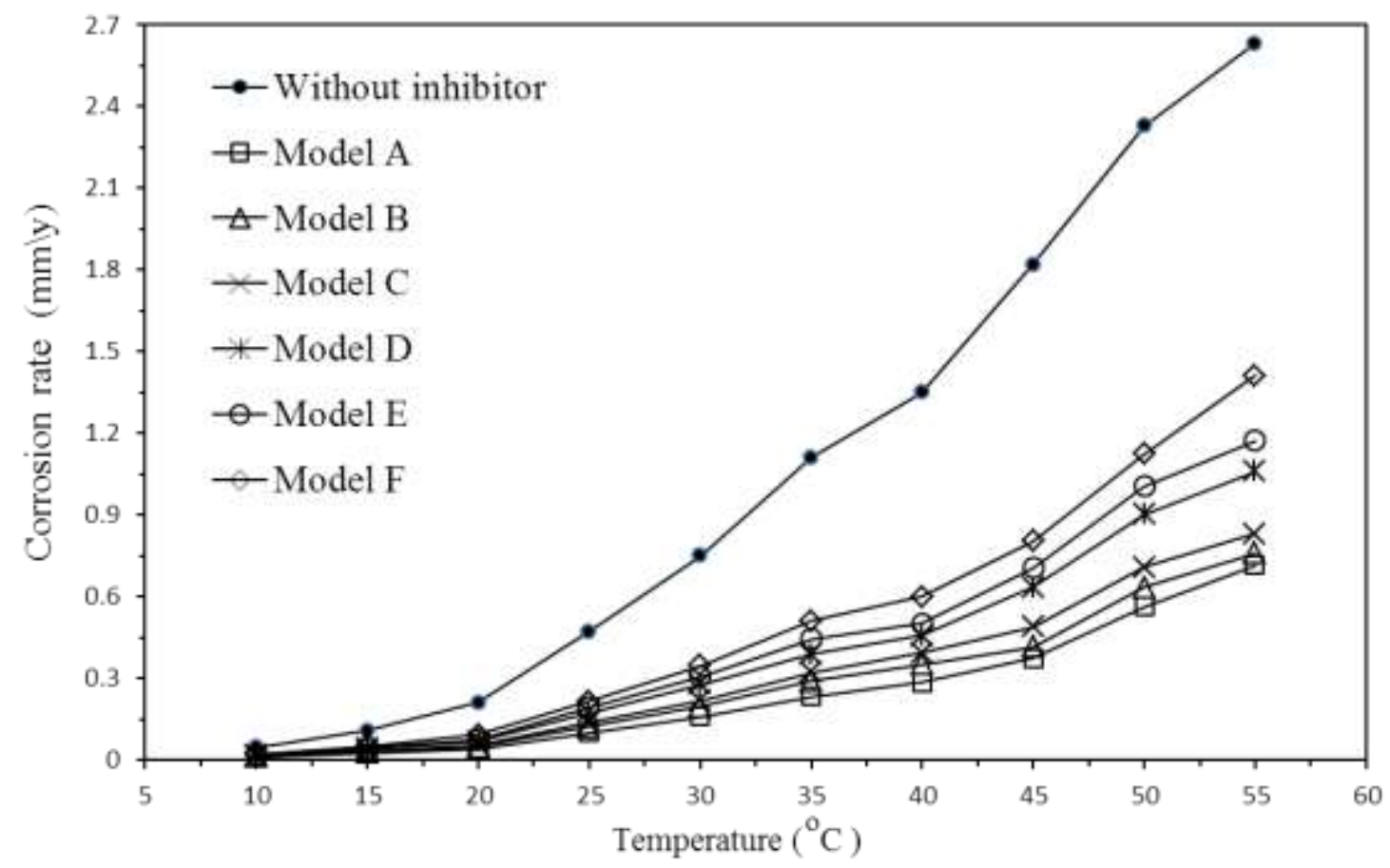

Figure 5: Corrosion Rate Of AISI 316 Steel Tested In Potable Water Before And After Added Of Inhibitors.

Table 5: Efficiency of Inhibitors at Various Temperatures.

\begin{tabular}{|c|c|c|c|c|c|c|c|c|c|c|}
\hline \multirow{2}{*}{$\begin{array}{c}\text { Inhibitors } \\
\text { types }\end{array}$} & \multicolumn{10}{|c|}{ Temperatures $\left({ }^{\circ} \mathrm{C}\right)$} \\
\cline { 2 - 12 } & 10 & 15 & 20 & 25 & 30 & 35 & 40 & 45 & 50 & 55 \\
\hline Model A & 77.32 & 78.97 & 78.98 & 78.93 & 79.00 & 78.97 & 78.96 & 79.05 & 75.14 & 72.83 \\
\hline Model B & 73.13 & 74.20 & 74.11 & 73.77 & 74.00 & 74.06 & 73.98 & 73.88 & 71.77 & 71.12 \\
\hline Model C & 70.05 & 71.20 & 71.34 & 70.81 & 71.20 & 71.18 & 71.15 & 71.10 & 69.63 & 68.48 \\
\hline Model D & 61.64 & 63.00 & 63.23 & 62.89 & 63.00 & 62.95 & 62.89 & 62.46 & 60.25 & 59.79 \\
\hline Model E & 58.22 & 59.00 & 58.67 & 58.96 & 59.02 & 58.92 & 58.87 & 58.30 & 56.90 & 55.44 \\
\hline Model F & 53.13 & 54.01 & 53.92 & 52.57 & 54.00 & 54.04 & 53.95 & 53.44 & 50.82 & 46.43 \\
\hline
\end{tabular}

The silicates or phosphates are inhibited the corrosion by initiating a slight layer on the specimens faces of stainless steel potable water tanks as it is fed through them. The layers are virtually indistinguishable and the inhibitor layer thick isn't increased in intensity with timing. After the inhibitor layer is produced, the protection is keep up only if the inhibitors fed are persistent; if fed is discontinued, the inhibition is progressively disappeared; if the inhibitor layers are broken, the layer is identity-soothing on condition that the inhibitor is continued supported [22].

In view of the fact that the formation of a protective layer was due to the adsorption of inhibitor molecules on the AISI 316 stainless steels. The difference in inhibitor efficiency between these types of inhibitors are returned to various factors related to the adsorption process of silicate and phosphate on the metal surfaces. The adsorption process is dependent on the compositions of the silicate and phosphate, the dissociation of the silicate and phosphate in the water solution, chemical changes, temperature, the nature of the surface charge on the metal-water and $\mathrm{pH}$ value of potable water.

The increasing of $\mathrm{E}_{\mathrm{corr}}$ in the direction of negative side demonstrations that the inhibitor molecule adsorption was on the site of cathode part. From this, we can use $\mathrm{E}_{\text {corr. }}$ as a referred for adsorption efficiency of the six types of inhibitors tested. This as $\mathrm{E}_{\text {corr. }}$ increased, it is works as increased a barrier from the strike of potable water destructive ions and increased the molecule of inhibitors participating in electrochemical process [23].

The silicate is a compound containing the silicon, oxygen, and one or two metals $\mathrm{Si}(\mathrm{OH})_{4}$. Silicate is reacted with stainless steel metal anions and the metal surface, i.e., it is adsorbed on anodic metal sites according to the following reaction [24]:<smiles>CC(C)O[N+]1(C)O[N+](C)(O)O[Si](C)(O)O1</smiles>

When injecting the phosphate inhibitor to the potable water, it is dissociated and constricted condensed inorganic layer varying from a simple to a long-chain linear phosphate. The formula of phosphates is $\left(\mathrm{PO}_{4}^{-3}\right)$ [25].

Both the silicate and phosphate inhibitors are included crystalline salts that dissociate in potable water constructing cations and anions. Only the 
negative anions like $\mathrm{SiO}_{3}^{-}$and $\mathrm{PO}_{4}^{-}$are contributed in reduced the corrosion process [26]. The $\mathrm{pH}$ value of water is important factor affects the inhibition rate because it influences the equilibrium between the various components of both silicate and phosphates inhibitor states. Increased of $\mathrm{pH}$ means increased acidity of water which leads to increase dissociation of protective film of inhibitor in water Therefore the inhibitor efficiency is decreased [26]. The Silicate and phosphate inhibitors are dissociated in potable water involves a chemical reaction shown in the following equations $[27,28]$ :

$$
\begin{gathered}
4 \mathrm{Si}(\mathrm{OH})_{4}(\mathrm{aq}) \stackrel{\text { temperature }}{2} \mathrm{Si}_{4} \mathrm{O}_{6}(\mathrm{OH})_{6}+ \\
\mathrm{Si}(\mathrm{OH})_{4}+\mathrm{OH}_{2} \mathrm{O} \longrightarrow(\mathrm{OH})_{3} \mathrm{SiO}^{-}+\mathrm{H}_{2} \mathrm{O} \\
\mathrm{PO}_{4}+\mathrm{H}_{2} \mathrm{O} \longrightarrow(7) \\
\longrightarrow \mathrm{H}_{3} \mathrm{PO}_{4}+\mathrm{OH}^{-}
\end{gathered}
$$

The process of adsorption of inhibitor based on phosphate or silicate in the exterior faces of the specimen is a substitution reaction between inhibitor particles or ions and water components. The silicate inhibitors adsorption processes are greater than the phosphate inhibitor. Adsorption of both silicate and phosphate will decrease by rising the temperature [29]. Since the silicate and phosphate corrosion inhibitor have more energy of adsorption compared to water, the components of water in contact with stainless steel specimen faces can simply substituted by silicate and phosphate molecules. These inhibitors covered the surfaces and do on increased protection process [30].

All dissolved salts, chloride, metals and gases in water effects the inhibition efficiency of both silicate and phosphate inhibitor. As given in Table 3, the dissolved oxygen is less than $5 \mathrm{mg} / \mathrm{l}$; the drinking water is normally involved a rich of $\mathrm{O}_{2}$ dissolved gas and it is corrosive gas until the oxidation layer is created in the surface. Both silicates and phosphate thin film inhibitor decrease the rate of cathodic reaction by restrictive the diffusion of $\mathrm{O}_{2}$ dissolved gas to the stainless steel surface. The oxygen is considering the main driving force for corrosion of stainless steel in potable water. This, the increase in corrosion with raising the temperature at a given oxygen concentration is due to more rapid oxygen diffusion occurring at higher temperatures [31].

The concentration of $\mathrm{Ca}$ is large than $\mathrm{Na}$ as given in Table 3. Both the calcium $\mathrm{Ca}$ and sodium $\mathrm{Na}$ ions do on reducing the phosphate and silicate inhibitor film solubility but the influences of $\mathrm{Ca}$ on solubility is a larger compared to influence of $\mathrm{Na}$ [32]. The chloride ions presents in potable water play a role in corrosion process. As seen in Table 3, the chloride concentration is $700 \mathrm{mg} / \mathrm{l}$. the chloride is the main causes of the stainless steel pitting corrosion and causes increased corrosion with temperature raise [33]. The reaction between sodium salts and silicate, phosphate and silicate/phosphate inhibitors is given by equation [34]:

$$
\begin{gathered}
\mathrm{Si}(\mathrm{OH})_{4}+\mathrm{Ca}^{+2} \longrightarrow \mathrm{CaSiO}_{3}+2 \mathrm{H}^{+}+\mathrm{H}_{2} \mathrm{O} \ldots(9) \\
2 \mathrm{PO}_{4}+3 \mathrm{Ca}^{+2} \longrightarrow \mathrm{Ca}_{3}\left(\mathrm{PO}_{4}\right)_{2} \underset{(10)}{\longrightarrow} \quad \ldots \mathrm{CaSiO}_{3} / \mathrm{PO}_{4} \\
\mathrm{Si}(\mathrm{OH})_{4}+\mathrm{PO}_{4}+\mathrm{Ca}^{+2} \underset{\text { (11) }}{+} \mathrm{CH}^{+}+\mathrm{H}_{2} \mathrm{O}
\end{gathered}
$$

Figure (6) illustrated the specimens surface corrosion morphology after Potentiostatic test at $25^{\circ} \mathrm{C}$. For model $\mathrm{E}$ and $\mathrm{F}$ of corrosion inhibitors, the surfaces of test sample that removed after conducted the Potentiostatic tests shows a great amount of oxidation commodities and pits, but for model A or B, the existence of certain pits on the surface were demonstrated in the surfaces. The specimens extracted from tested in potable water in presence of models $C$ and $\mathrm{D}$ inhibitor show pits and corrosion products precipitation on various points on surfaces. This appearance of the localized corrosion in specimen surfaces is occurs because of the different corrosion behavior and due to the presence of salts and ions practically chloride ions in potable water and due to effect of testing temperatures. It can be obviously viewed that the stainless steel surface was slight damaged and some zones have not a uniform corrosion.

\section{Conclusions:}

The performances of six types of corrosion inhibitors were evaluated for stainless steel in potable water, using a Potentiostatic corrosion test under different temperature. The Tafel constants and corrosion levels obtained from the Potentiostatic corrosion test indicated that better corrosion protected in case of the existence of inhibitors in comparison with cases without use of an inhibitor. The use of silicate corrosion inhibitors in AISI 316 stainless steel potable water tanks provide more efficiency compared to use of the phosphate alone or used combined silicate/phosphate corrosion inhibitors. The six types of inhibitors tested give good efficiency under temperature $45^{\circ} \mathrm{C}$, but when raising the temperature more than $45^{\circ} \mathrm{C}$, there is concomitant noticeable droppings in the inhibitor efficiency. This indicates that the inhibitor film produced on the surface of specimen tested has a lower separation or protective in quality at larger values of temperature range. It's found that the effect of water components in inhibitor layer and diffusion process of silicate inhibitor is less compared to phosphate or silicate/phosphate corrosion inhibitors. Also, it's noted that the pitting corrosion is demonstrated on the specimen surfaces with existing or absence of inhibitors due to effect of chloride ions in water. It's found that the best or optimum efficiency obtained for the test inhibitors used are different with temperatures. The optimum efficiency obtained for model $\mathrm{A}$ at $45^{\circ} \mathrm{C}$, for model $\mathrm{B}$ at $15^{\circ} \mathrm{C}$, for model $\mathrm{C}$ at $25^{\circ} \mathrm{C}$, for model $\mathrm{D}$ at $20^{\circ} \mathrm{C}$, for model $\mathrm{E}$ at $30^{\circ} \mathrm{C}$, and for model $\mathrm{F}$ at $35^{\circ} \mathrm{C}$. 

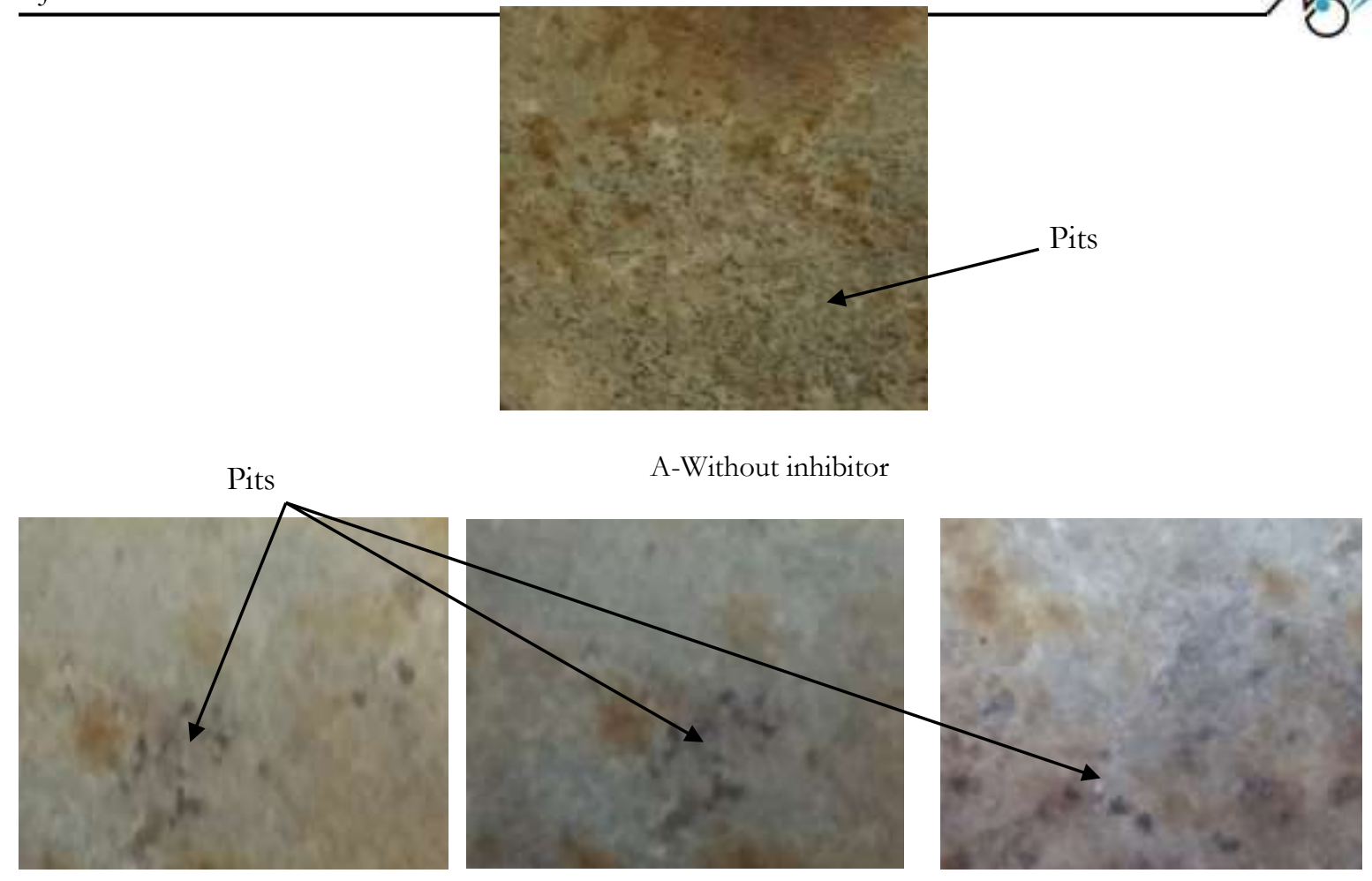

B- Model A

C- Model B

D- Model C

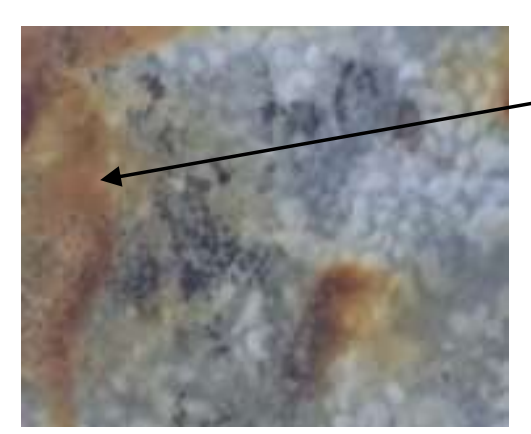

E- Model D.

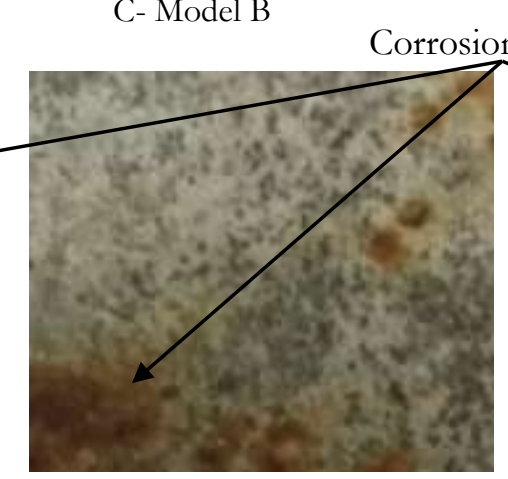

F- Model E.

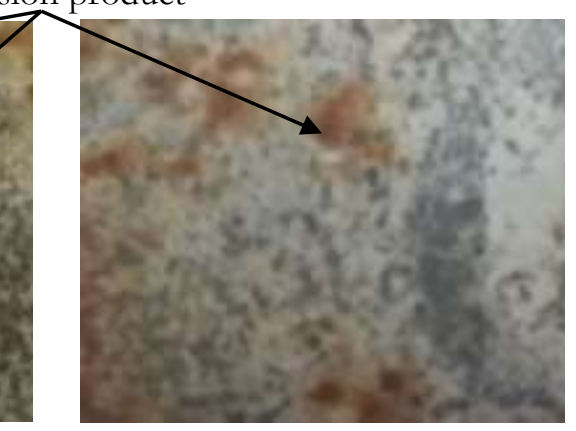

G- Model F.

Figure 6: The Surface of Specimens After Potentiostatic Corrosion Test at $25^{\circ} \mathrm{C}$.

\section{References:}

[1] B. Kajarekar, A. Gangurde, K. Gunjal, D. Bhalchim and D. S. Yewale, "Comparative estimation of underground water tank and elevated storage tank of Junnar", International Journal of Advance Engineering and Research Development, Vol.5, No.4, pp.1-7, 2018.

[2] R. Avery, S. Lamb, C. Powelland, and A.Tuthill, "Stainless steel for potable water treatment plants", NIDI Technical Series Report, No.10087, 1999.

[3] Application for stainless steel in the water industry, IGN-4-25-02, Report of Stainless Steel Construction Institute, UK, 1999.

[4] R. Garcia, B. Valdez, M. Schorr, and A. Eliezer, "Green corrosion inhibitors for water systems", Materials Performance, Vol.52, No.6, pp.48-51, 2013. [5] G. G. Dariva and A. F. Galio, "Corrosion inhibitors-principles, mechanisms and applications in developments in corrosion protection", Aliofkhazraei M., Editor, Edition by Intech Open, London, United Kingdom, 2014.
[6] R. G. Kelly, D. W. Shoesmith, R. J. Scully, and R. G. Buchheit, "Electrochemical techniques in corrosion science and engineering", Editor by Philip A. Schweitzer, Marcel Dekker Inc., New York, USA, 2002.

[7] N. Cheng, B. V. Salas, M. S. Wiener and J. Ricardo, "Saline, natural, and industrial environment humid and saline, natural, and industrial environments", Chapter 8, Corrosion Inhibitors, Principles and Recent Applications, Web of Science, 2019.

[8] W. P. Singh, "Toxicity Issues of Organic Corrosion Inhibitors: Applications of QSAR Model", CORROSION 96, 24-29 March, Denver, Colorado, pp.1-16, USA, 1996.

[9] H. H. Strehblow, "Mechanism of pitting corrosion", Corrosion Mechanisms in Theory and Practice, Eds. by Marcus P. and J. Oudar, Marcel Dekker Inc., New York, USA, 1995.

[10] A. Nausha, A. U. Malik, and S. Ahmed, "Corrosion prevention with sodium silicate", Report of Saline Water Conversion Corporation, Technical 
Report N0.TR3804/EVP95013, Kingdom of Saudi Arabia, 1998.

[11] L. S. McNeill, and M. Edwards, "Iron pipe corrosion in distribution systems", Journal American Water Works Association, Vol.93, No.7, pp.88-100, 2001.

[12] M. M. Ebrahimi, T. Shahrabi, and Hosseini M. G., "Determination of suitable corrosion inhibitor formulation for a potable water supply", AntiCorrosion Methods and Materials, Vol.51, No.6, pp.399-405, 2004.

[13] T. Mathiesen, and J. E. Frantsen, "Unusual corrosion failures of stainless steel in low chloride waters", NACE Corrosion 2008, Paper 08174, pp.113, New Orleans, LA, USA.

[14] I. K. Nurul and K. Jain, "The effect of temperature on the corrosion inhibition of mild steel in $1 \mathrm{M} \mathrm{HCl}$ solution by curcuma longa extract", Int. J. Electrochem. Sci., Vol.8, pp.7138 -7155, 2013.

[15] G. Daniela, "The use of phosphate-silicate inhibitor, in corrosion control of drinking water distribution system" American J. of Appl. Scientific Research, vol. 2, No.6, pp.97-102, 2016.

[16] S. B. Kazem, and D. Changiz, "Corrosion inhibition of sodium phosphate for coarse and near ultrafined-grain mild steel surface", Journal of Ultrafine Grained and Nanostructured Materials, Vol.50, No.1, pp.33-42, 2017.

[17] P. C. Angelo, and B. Ravisankar, "Introduction to Steels: Processing, Properties, and Applications", CRC Press Published, 2019, USA.

[18] L. T. Judy, E. S. Barry, R. S. Michael, A. L. Darren, and J. D. Patrick, "Sodium silicate corrosion inhibitors: issues of effectiveness and mechanism", Water Quality Technology Conference (AWWA), November 9-12, 1997, Denver, USA.

[19] ASTM G5-87, "Standard reference test method for making Potentiostatic and Potentiodynamic anodic polarization measurements", Report of the American Society for Testing and Materials, 1987.

[20] ASTM G 102-89, "Standard practice for calculation of corrosion rates and related information from electrochemical measurements", Report of the American Society for Testing and Materials, PA., USA, 1999.

[21] N. Mohamada, N. K. Othmana, and A. Jalarb, "Investigation of $\mathrm{SiO}_{2}: \mathrm{Na}_{2} \mathrm{O}$ ratio as a corrosion inhibitor for metal alloys", AIP Conference Proceedings 1571, Malaysia, 2013.

[22] B. M. Fernando, A. M. F. Anne, E. R. D. F. Alan, and A. M. A. J. Andre, "The use of sodium silicate as a corrosion inhibitor in a saline drilling fluid: a nonaggressive option to the environment", Journal of Environmental Protection, Vol.7, pp.2025-2035, 2016.
[23] S. A. X. Stango and U. Vijayalakshmi, "Studies on corrosion inhibitory effect and adsorption behavior of waste materials on mild steel in acidic medium", J. of Asian Cer. Soc., Vol.6, No.1, 2018.

[24] Y. J. Tan, S. Bailey and B. Kinsella, "The monitoring of the formation and destruction of corrosion inhibitor films using electrochemical noise analysis (ENA)", Corrosion science, vol.38, no.10, pp.1681-1695, 1996.

[25] A. Ali Alshehri, "Impact of corrosion inhibitor blended orthophosphate on water quality in water distribution systems", Ph.D. Thesis, Department of Civil and Environmental Eng., University of Central Florida, USA, 2008.

[26] L. Liang, T. C. Ting, W. Z. Qi, and W. C. Chong, "Organic phosphorus compounds as inhibitors of corrosion of carbon steel in circulating cooling water: weight loss method and thermodynamic and quantum chemical studies", Advances in Materials Science and Engineering, Vol.2018, pp.1-9, 2018.

[27] D. A. Meier and L. Dubin, "A novel approach to silica scale inhibition”, Paper No. 334, Corrosion/87, NACE International Report, Houston, USA, 1987.

[28] Handbook of Crystal Growth, Edited by Govindhan D., B. Kullaiah, P. Vishwanath, and Michael D., 2010, Springer, New York, USA.

[29] Dinh Q. H., Tran D., and Pham C. N., "Effect of the structure and temperature on corrosion inhibition of thiourea derivatives in $1.0 \mathrm{M} \mathrm{HCl}$ solution", ACS Omega, Vol.4, No.11, pp.14478-14489, 2019.

[30] Richard J. H., and Ya F. Z., "Competitive and noncompetitive adsorption of silicate and phosphate by two acid Si-deficient soils and their effects on P and Si extractability", Journal Soil Science and Plant Nutrition, Vol.64, No.4, pp.1-8, 2018.

[31] A. A. Mohamed, "Inhibition of mild steel corrosion in cooling systems by low- and nontoxic corrosion inhibitors", Ph.D. Thesis, Faculty of Science and Engineering, School of Materials, Manchester University, USA, 2016.

[32] W. L. Marshall and J. M. Warakomski, "Amorphous silica solubilities, II: Effect of aqueous salt solutions at $25^{\circ} \mathrm{C}$ ", Geochim Cosmochim Acta, Vol.44, pp.915-917, 1980.

[33] M. Cabrini, F. Fontana, S. Lorenzi, T. Pastore, and S. Pellegrini, "Effect of organic inhibitors on chloride corrosion of steel rebars in alkaline pore solution", J. of Chemistry, Vol.2015, pp.1-10, 2015.

[34] S. K. Dumpawar, "Calcium silicate/phosphate inhibitors for corrosion control of hot dipped galvanized and cold rolled steels", M.Sc. Thesis, Metallurgical and Materials Engineering, National Institute of Technology Rourkela, India, 2012. 